\title{
INFLUENCE OF CYBERCHONDRIA ON ORTHODONTICS - A QUESTIONNAIRE BASED STUDY
}

\author{
Dr. Pankaj Akhare ${ }^{1}$, Dr. Nandini Jaiswal ${ }^{2}$, Dr. Harish Atram ${ }^{3}$, Dr. Akanksha Kumar ${ }^{4}$, Dr. Pratik Jaltare ${ }^{4}$, \\ Dr. Kshitij Sabley ${ }^{4}$
}

1- Professor \& Guide, 2- Postgraduate Student, 3- Reader, 4- Senior Lecturer, Department Of Orthodontics and Dentofacial Orthopaedics, Swargiya Dadasaheb Kalmegh Smruti Dental College and Hospital, Nagpur

\section{ABSTRACT}

Objective: To identify how the use of internet by patients has influenced the way of imparting Orthodontic treatment and how the Orthodontist themselves make use of the Internet for their own development. Methods: A survey spanning over a period of 3 months was conducted among 100 Orthodontists and Orthodontic postgraduate students enrolled in Orthodontics 3 years residency program. Data was collected via a questionnaire, sent to Orthodontists and post graduate students through mail. Results: About one half of the orthodontists experienced positive change in attitude of patients seeking information from internet and felt that it is beneficial for continued success of their patients but majority of Orthodontists believed that patient can be misled by internet and it may at times lead to unrealistic patient expectations and dissatisfaction. Conclusions: This study suggests that the impact of the Internet on orthodontics is overall on the negative side, but there is still a long way to go before its potential benefits can be realised.

Keywords: Cyberchondria, Orthodontics, Influence

\section{INTRODUCTION}

The Internet has completely changed the way people access information and since several years now represents the first source of information for many patients. ${ }^{1}$

The term social media (SM) generally refers to Internet tools that allow individuals and community to gather, communicate, and share information, opinions, photos, videos, and other contents within Internet applications. ${ }^{1}$

The development and expansion of the Internet represents one of the greatest advances in our ability to communicate and disseminate knowledge. ${ }^{2}$ In the last decade, the percentage of adults who have accessed the Internet to look for health information has rapidly increased. ${ }^{3}$
Large amounts of medical and dental information are now widely available on the Internet and easily accessible to those with Internet access. ${ }^{4}$

The Internet has tremendous potential to influence health and health care. ${ }^{2}$ The internet has the potential to educate and empower the patients, by providing information on treatment modalities and supporting self-help and patient choice. ${ }^{5}$ The development of information and services from internet encourage consumers to become more responsible for their own health, and to actively participate in health-related decisions that affect them. ${ }^{6}$

The majority of orthodontic treatments are based 
upon patient co-operation and motivation. The use of Internet-based social media sites to investigate the experiences and attitudes of orthodontic patients seems rather appealing, since teenagers and adolescents have abundant access to the Internet. ${ }^{7}$

Use of social media by patients for health related reasons provides different effects, which can result in both benefits and challenges. It is important to identify these effects of social media for the healthcare system, as a growing percentage of patients use social media for health-related reasons. ${ }^{8}$

A significant disadvantage of using social media for learning, as it is difficult to ascertain the validity of the information given. ${ }^{9}$

Social media has shown to be widely used in self and business promotion, to develop a 'digital voice'. Social media allows links to the professional community, which can provide much needed support, feedback and education to clinicians. ${ }^{9}$

Many doctors, however, report putting a lot of time and effort into social media campaigns without seeing much return on their investment. ${ }^{10}$

Clinicians need to understand the possibilities of this technology, and to be aware of potential threats to health. ${ }^{5}$

Hence, the current study was undertaken with the aim to answer on how the internet use by patients has impacted orthodontic treatment and the how the orthodontist themselves make use of internet for their development.

\section{MATERIAL AND METHOD}

A cross-sectional questionnaire survey was carried out between November 2019 to January 2020 among 100 orthodontists and Orthodontic post graduate students, after obtaining their informed consent.

The sample size was calculated by simple random sampling
Data was collected via a prestructured questionnaire consisting of 18 questions, sent to orthodontist and Orthodontic post graduate students through mail. Email address of every orthodontist included in the survey was saved for record purpose.

Questions included in the survey were to investigate how the internet use by the patients for finding information about treatment modalities has impact on orthodontic treatment and how it affects orthodontist- patient relationship. The questions were also based on how the orthodontists themselves make use of the internet as an oral health education resource.

\section{STATISTICAL ANALYSIS}

The responses received were subjected to statistical analysis by using descriptive and inferential statistics using z-test for single proportion. Software used in the analysis was SPSS 24.0 and $\mathrm{p}<0.05$ is considered as level of significance.

\section{RESULTS}

Tables 1, 2 and 3 and Fig. 1 shows the responses received to the questionnaire in the survey.

\section{Years of practice of the participants}

On evaluation of responses received, $85 \%$ of the orthodontist were in the practice from less than 5 years, $10 \%$ were in the practice from 5-10 years, $3 \%$ were in practice from 11-15 years and $2 \%$ of them were in practice from more than 15 years. By using z-test for single proportion statistically significant difference was found in duration of practice of orthodontist $(\mathrm{z}=23.80)$.

\section{Age group of patients who have inquisitively made use of internet before orthodontic treatment}

Orthodontist responding to the questionnaire stated that in 1 year they came across $10 \%$ of patients who were less than 15 years of age, $47 \%$ of patients were 15 to 20 years of age and $33 \%$ were in 21 to 25 and $10 \%$ were above 25 years of age, who made use of internet before orthodontic treatment. 
Table 1. Questions based on the information mostly searched by the patients on internet

\begin{tabular}{|c|c|c|c|c|c|c|c|}
\hline $\mathrm{Sr}$ & Questions & \multicolumn{4}{|c|}{ Responses (\%) } & z- & Significance \\
\hline \multirow{2}{*}{$\begin{array}{c}\text { No. } \\
1 .\end{array}$} & \multirow[t]{2}{*}{$\begin{array}{l}\text { How long have you } \\
\text { been in orthodontic } \\
\text { practice? }\end{array}$} & $>5$ years & 5-10 years & 11-15 years & $\begin{array}{c}>15 \\
\text { years }\end{array}$ & \multirow{2}{*}{23.80} & \multirow{2}{*}{ Significant } \\
\hline & & 85 & 10 & 3 & 2 & & \\
\hline \multirow[t]{2}{*}{2.} & \multirow{2}{*}{$\begin{array}{l}\text { Which age group of } \\
\text { patients, have you } \\
\text { frequently come } \\
\text { across who have } \\
\text { inquisitively made } \\
\text { use of internet } \\
\text { before coming for } \\
\text { orthodontic } \\
\text { treatment? }\end{array}$} & $\begin{array}{c}<15 \\
\text { years of } \\
\text { age in } 1 \\
\text { year. }\end{array}$ & $\begin{array}{c}15-20 \\
\text { years of } \\
\text { age in } 1 \\
\text { year }\end{array}$ & $\begin{array}{c}21-25 \\
\text { years of } \\
\text { age in } 1 \\
\text { year }\end{array}$ & $\begin{array}{c}>25 \\
\text { years of } \\
\text { age in } 1 \\
\text { year }\end{array}$ & \multirow{2}{*}{3.33} & \multirow{2}{*}{ Significant } \\
\hline & & 10 & 47 & 33 & 10 & & \\
\hline \multirow[t]{2}{*}{3.} & \multirow[t]{2}{*}{$\begin{array}{l}\text { What type of } \\
\text { information is most } \\
\text { likely to be searched } \\
\text { using internet by } \\
\text { patients seeking } \\
\text { orthodontic } \\
\text { treatment? }\end{array}$} & $\begin{array}{l}\text { Types of } \\
\text { brackets }\end{array}$ & $\begin{array}{l}\text { Duration } \\
\text { of } \\
\text { treatment }\end{array}$ & $\begin{array}{c}\text { Cost of } \\
\text { treatment }\end{array}$ & $\begin{array}{l}\text { Consequ } \\
\text { ences of } \\
\text { orthodo } \\
\text { ntic } \\
\text { treatme } \\
\text { nt } \\
\end{array}$ & \multirow[t]{2}{*}{7.02} & \multirow[t]{2}{*}{ Significant } \\
\hline & & 33 & 15 & 13 & 39 & & \\
\hline \multirow[t]{2}{*}{4.} & \multirow{2}{*}{$\begin{array}{l}\text { How frequently do } \\
\text { patients inquire } \\
\text { about orthodontic } \\
\text { appliances after } \\
\text { checking it out on } \\
\text { the internet? }\end{array}$} & $\begin{array}{l}<5 \text { times } \\
\text { in } 1 \text { year }\end{array}$ & $\begin{array}{c}5-10 \\
\text { times in } 1 \\
\text { year }\end{array}$ & $\begin{array}{c}11-15 \\
\text { times in } 1 \\
\text { year }\end{array}$ & $\begin{array}{l}>15 \\
\text { times in } \\
1 \text { year }\end{array}$ & \multirow{2}{*}{9.05} & \multirow[t]{2}{*}{ Significant } \\
\hline & & 45 & 45 & 5 & 5 & & \\
\hline
\end{tabular}

Table 2. Questions pertaining to the perception of Orthodontist on the use of internet by patients

\begin{tabular}{|c|l|c|c|c|c|c|}
\hline Sr & \multicolumn{1}{|c|}{ Questions } & \multicolumn{3}{|c|}{ Responses (\%) } & $\begin{array}{c}\text { z- } \\
\text { value }\end{array}$ & Significance \\
\hline 1. & $\begin{array}{l}\text { What kind of change have you } \\
\text { experienced in the attitude of the } \\
\text { patients seeking information from } \\
\text { internet prior to the appointment? }\end{array}$ & $\begin{array}{l}\text { Positive } \\
\text { change }\end{array}$ & $\begin{array}{l}\text { Negative } \\
\text { change }\end{array}$ & $\begin{array}{c}\text { No } \\
\text { change }\end{array}$ & & \\
\cline { 3 - 7 } & 54 & 41 & 5 & 10.83 & Significant \\
\hline
\end{tabular}


Table 2. (Contd.): Questions pertaining to the perception of Orthodontist on the use of internet by patients.

\begin{tabular}{|c|c|c|c|c|c|}
\hline \multirow{2}{*}{$\begin{array}{l}\text { Sr } \\
\text { No. }\end{array}$} & \multirow[t]{2}{*}{ Questions } & \multicolumn{2}{|c|}{ Responses (\%) } & \multirow{2}{*}{$\begin{array}{c}\text { Z- } \\
\text { value }\end{array}$} & \multirow[t]{2}{*}{ Significance } \\
\hline & & Yes & No & & \\
\hline 2. & $\begin{array}{l}\text { Is internet a useful source of } \\
\text { information regarding orthodontic } \\
\text { treatment for patients? }\end{array}$ & 62 & 38 & 12.77 & 12.77 \\
\hline 3. & $\begin{array}{l}\text { Do you think, internet play a role } \\
\text { in guiding patients towards } \\
\text { formulating their own treatment } \\
\text { plan? }\end{array}$ & 62 & 38 & 12.77 & Significant \\
\hline 4. & $\begin{array}{l}\text { Do you perceive that internet } \\
\text { derived information has led to } \\
\text { increased patient dis-satisfaction? }\end{array}$ & 82 & 18 & 21.34 & Significant \\
\hline 5. & $\begin{array}{l}\text { Has gaining of information from } \\
\text { the internet led to patients } \\
\text { demanding for more complex } \\
\text { orthodontic treatment? }\end{array}$ & 77 & 23 & 18.30 & Significant \\
\hline 6. & $\begin{array}{l}\text { Does internet foster demand for } \\
\text { inappropriate intervention? }\end{array}$ & 70 & 30 & 15.28 & Significant \\
\hline 7. & $\begin{array}{l}\text { Does information gained from the } \\
\text { internet about orthodontic } \\
\text { treatment likely to be } \\
\text { misinterpreted by the patients? }\end{array}$ & 95 & 5 & 43.59 & Significant \\
\hline 8. & $\begin{array}{l}\text { Having to take time to talk to } \\
\text { patients about information that } \\
\text { they have obtained from the } \\
\text { internet is a burden? }\end{array}$ & 62 & 38 & 12.77 & Significant \\
\hline 9. & $\begin{array}{l}\text { Do you think, patients can be } \\
\text { misled by internet rather than } \\
\text { benefiting from it? }\end{array}$ & 92 & 8 & 33.91 & Significant \\
\hline 10. & $\begin{array}{l}\text { Do you think, internet use by } \\
\text { patients represent a threat to the } \\
\text { 'dentist-patient' relationship? }\end{array}$ & 67 & 33 & 14.25 & Significant \\
\hline 11. & $\begin{array}{l}\text { Is the use of internet beneficial for } \\
\text { continued success of our patient's } \\
\text { treatment? }\end{array}$ & 49 & 51 & 9.80 & Significant \\
\hline
\end{tabular}




\section{Table 3. Questions pertaining to the use of internet by the Orthodontists for their own development}

\begin{tabular}{|c|l|c|c|c|c|}
\hline $\begin{array}{c}\text { Sr } \\
\text { No. }\end{array}$ & \multicolumn{1}{|c|}{ Questions } & Yes (\%) & No (\%) & $\begin{array}{c}\text { z- } \\
\text { value }\end{array}$ & Significance \\
\hline 1. & $\begin{array}{l}\text { Do you believe that reminding patients } \\
\text { using internet/mobile applications } \\
\text { about appointments, oral hygiene } \\
\text { would be beneficial? }\end{array}$ & 92 & 8 & 33.91 & Significant \\
\hline 2. & $\begin{array}{l}\text { Do you use the internet as an oral } \\
\text { health education resource? }\end{array}$ & 69 & 31 & 14.92 & Significant \\
\hline 3. & $\begin{array}{l}\text { Do you use the internet to explain } \\
\text { treatment modalities directly to } \\
\text { patients? }\end{array}$ & 41 & 59 & 8.34 & Significant \\
\hline
\end{tabular}

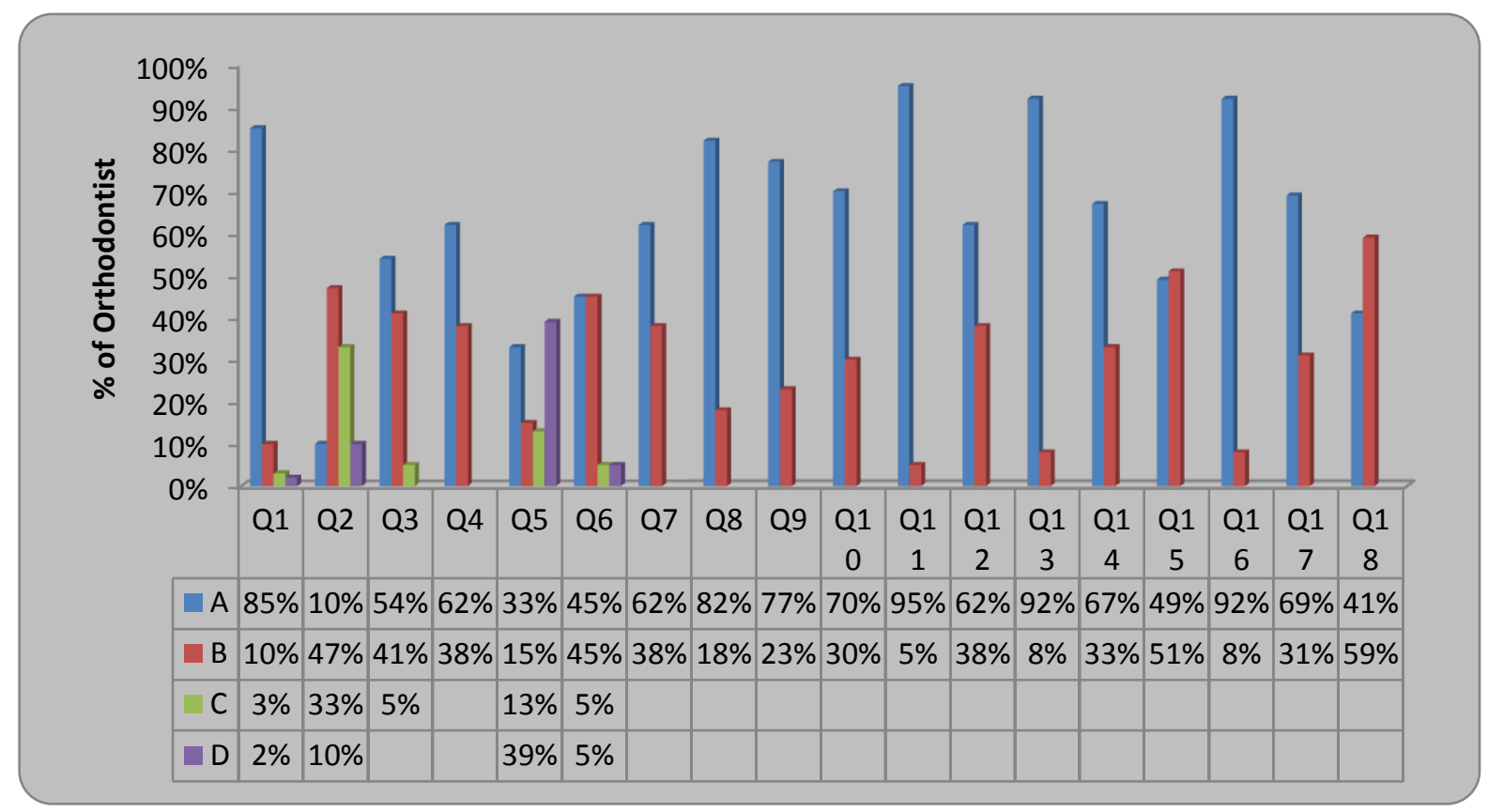

Fig. I: Responses of Orthodontists obtained from the Questionnaire

\section{Perceptions of patient use of the internet}

$54 \%$ of Orthodontists experienced positive change in attitude of patients after internet use. $62 \%$ of orthodontists perceive that internet is a useful source of information for the patients while majority of orthodont- ists agreed that patients were likely to misinterpret such information and $92 \%$ of Orthodontists believed that patients can be misled by internet rather than benefiting from it.

$45 \%$ of Orthodontists stated that patients inquire or asked about orthodontic appliances less than 5 times 
in a year. When questioned on specific topics that patients had asked about orthodontic treatment, it is apparent that patients (39\%) mostly asked about consequences of orthodontic treatment.

\section{Perception of the impact of internet use by patients on orthodontic treatment}

$62 \%$ of Orthodontists felt that internet play a role in guiding patients towards formulating their own treatment plan and discussing about the information that patients had obtained from the internet is burden for them. In total, $77 \%$ of orthodontists agreed that information gained from the internet had led to patients demanding more complex treatment and $70 \%$ reported that patients had demanded inappropriate care. Majority of Orthodontists (82\%) felt internet derived information has led to increased patient dis-satisfaction and $67 \%$ viewed the internet as a threat to dentist-patient relationship.

One half $(49 \%)$ of the Orthodontists felt that internet is beneficial for continued professional development.

\section{Practitioner's own use of the internet}

The final stage of the questionnaire enquired about practitioner's own use of internet.

Most of the Orthodontists (92\%) believed that reminding patients about appointments and oral hygiene through mobile application is beneficial.

In total $69 \%$ of the orthodontist use internet as an oral health education resource and $41 \%$ claimed that they use internet to explain about treatment modalities.

\section{DISCUSSION}

Although there has been considerable research into the impact of the internet on medical and dental care in general, its impact on orthodontic treatment has not been examined till date. Hence, this survey was aimed to determine how patients' use of internet has influenced the orthodontic treatment and how the orthodontist themselves make use of the internet.

The results of this study can be viewed as a true representation of how the internet has impacted orthodontic treatment.

J A Powell and colleagues in a review of 'The doctor, the patient and the world-wide web' concluded that internet has the potential to improve the effective and efficient delivery of healthcare, educate consumers, support decision-making, enable interaction between consumers and professionals, and reduce inequalities in health. ${ }^{5}$ In our study, nearly about one half of the orthodontists participating in our study experienced positive change in attitude of patients seeking information from internet and felt that it is beneficial for continued success of the patients but majority of orthodontists agreed that patient can be misled by internet and it may lead to patient dis-satisfaction.

Anderson and colleagues, in a review titled 'The Impact of Cyber Healthcare on the Physician-

Patient Relationship', suggested that the Internet is changing the ways in which physicians and their patients interact with one another. ${ }^{6}$ One of the most important effects of the Internet will be to amplify the patient's role in managing his/her own health. ${ }^{6}$ In the current study, higher proportion of orthodontists viewed the Internet as a threat to the dentist-patient relationship. However, the majority of orthodontists agreed that the Internet has led to patients demanding more complex or inappropriate care and having to take time to talk to patients about information from the Internet is a burden.

In a study by Henzell $\mathrm{M}$ and colleagues 'social Media Use by Orthodontic patients, ${ }^{7}$, they concluded that a large proportion of orthodontic patients use Internet-based social media sites. Social media sites may provide a useful channel of communication for patients seeking support. Further research is needed to evaluate the use of phone reminder applications in orthodontics. ${ }^{7}$ In our study $45 \%$ of orthodontist came across the patients 
who inquire about orthodontic appliances after checking it out on internet but this happened less than 5 times in 1 year and majority of orthodontist believe that reminding patients about appointments and oral hygiene through mobile applications is beneficial.

S. Bhola et al. conducted a study titled 'The risks and benefits of social media in dental foundation training' and concluded that social media can be a key tool in enhancing education and social networks are an invaluable and under-utilised educational resource, for trainees and more experienced clinicians alike. ${ }^{9}$ In our study, majority of orthodontist $(69 \%)$ use internet as a oral health education resource and $41 \%$ of orthodontist use internet to explain about treatment modalities.

\section{CONCLUSION}

This study suggests that the impact of the Internet on orthodontics is overall on the negative side because majority of orthodontists believed that patient can be misled by internet and it may at times lead to unrealistic patient expectations and dissatisfaction and higher proportion of orthodontists viewed internet as a threat to the dentist-patient relationship, but there is still a long way to go before its potential benefits can be realised.

Financial support and sponsorship: Nil.

Conflicts of interest: There are no conflicts of interest

\section{REFERENCES}

1. De Martino I, D'Apolito R, McLawhorn AS, Fehring KA, Sculco PK, Gasparini G. Social media for patients: benefits and drawbacks. Current reviews in musculoskeletal medicine. 2017; 10 (1):141-5.

2. Chestnutt IG, Reynolds K. Perceptions of how the Internet has impacted on dentistry. British Dent journal. 2006; 200(3):161-5.

3. McMullan M. Patients using the Internet to obtain health information: how this affects the patient-health professional relationship. Patient education and counseling. 2006; 63(1-2):24-8.

4. De Boer MJ, Versteegen GJ, Van Wijhe M. Patients' use of the Internet for pain-related medical information. Patient education and counseling. 2007;68(1):86-97.

5. Powell JA, Darvell M, Gray JA. The doctor, the patient and the world-wide web: how the internet is changing healthcare. Journal of the royal society of medicine. 2003; 96(2):74-6.

6. Anderson JG, Rainey MR, Eysenbach G. The impact of Cyber Healthcare on the physicianpatient relationship. Journal of medical systems. 2003; 27(1):67-84.

7. Henzell M, Knight A, Antoun JS, Farella M. Social media use by orthodontic patients. NZ Dent J. 2013;109(4):130-3.

8. Smailhodzic E, Hooijsma W, Boonstra A, Langley DJ. Social media use in healthcare: a systematic review of effects on patients and on their relationship with healthcare professionals. BMC health services research. 2016;16(1):442.

9. Bhola S, Hellyer P. The risks and benefits of social media in dental foundation training. British dental journal. 2016; 221(10):609.

10. Jorgensen G. Social media basics for orthodontists. American Journal of Orthodontics and Dentofacial Orthopedics. 2012; 141(4):510-5. 